The second concern is that irradiation may be used to conceal bacterial contamination of spoilt food without inactivating toxins generated by the earlier bacterial contamination..$^{10}$ But the same need for good hygiene applies equally to other food processes like canning and freezing. Thirdly, there could be a novel pattern of nutrient loss either from the radiation or because irradiated "fresh" foods may be older when they are eaten. The British committee conceded that data on the effects of irradiation on the nutrient content of food are not comprehensive-but they are more extensive than for many accepted methods of food processing. The committee recommended that if irradiation is permitted in Britain the nutrient content of irradiated food and its consumption pattern should be monitored. The fourth worry is that we are unable to recognise that a food has been irradiated. Several laboratories have searched for substances that would enable an analyst to diagnose that a food had been irradiated. It is unlikely that any characteristic substance would be found across all types of foods after low dose irradiation, but different diagnostic substances might yet be found in individual foods.

I see no reason why the government should not permit irradiation of stored winter potatoes and onions at $1 \mathrm{kGy}$ and of listed spices at moderate dosage. This should be coupled with registration and control of all irradiation plants and clear labelling regulations. One problem is that the toxicological evidence is poorly collected, reviewed, and presented. The World Health Organisation is planning a publication, ${ }^{5}$ and I hope that this-or perhaps a government publicationcan assemble the large amount of toxicological work that has been done over the past 30 years in the International Project in the Field of Food Irradiation, in the United States, at Leatherhead in Britain, and in many other countries.

A Stewart Truswell Professor of human nutrition, University of Sydney

Wolfson College,

Oxford OX2 6UD

1 Ministry of Health. Irradiation of food. London: HMSO, 1964. (Committee on Medical and Nutritional Aspects of Food Policy. Report of the working party.)

2 Department of Health and Social Security, Ministry of Agriculture, Fisheries and Food. Report on the safety and wholesomeness of irradiated foods by the advisory committee on irradiated and novel the safely and wholesomeness of

3 Food and Agriculture Organisation, International Atomic Energy Authority, World Health Organisation. Wholesomeness of irradiated food. Geneva: WHO, 1981. (WHO Technical Report Series No 659.)

4 Codex Alimentarius Commission. Codex general standard for irradiated foods and recommended international code of practice for the operation of radiation facilities used in the treatment of fonds. Vol 15, edition 1. Rome: CAC, 1984.

5 World Health Organisation. Food irradiation. Geneva: WHO, 1987. (In Point of Fact No 40.)

6 Kader AA. Potential applications of ionizing radiation in postharvest handling of fresh fruits and vegetables. Food Technology 1986;40:117-21.

7 United States Department of Health and Human Services, Food and Drug Administration. Irradiation in the production, processing and handling of food; final rule. Washington DC: US Government Printing Office, 1986. (FDA 21: CFR Part 179. Federal Register 18 April: 51 No 75 .)

8 Anonymous. More research into safety of irradiated food urged. [News.] BMA News Review 1987 April:11.

9 British Medical Association, Board of Science and Education. Irradiation of foodstuffs. London: BMA, 1987.

10 Webb T, Lang T. Food irradiation: the facts. Wellingborough, Northants: Thorsons, 1987.

11 Bhaskaram C, Sadasivan G. Effects of feeding irradiated wheat to malnourished children. Am $\mathcal{J}$ Clin Nutr 1975;28:130-5.

12 Kesavan PC. Indirect effects of radiation in relation to food: facts and fallacies. Fournal of Nuclear and Agricultural Biology 1978;7:93-7.

13 Brynjolfsson A. Wholesomeness of irradiated foods: a review. Journal of Food Safety 1985;7: $107-26$.

14 Food and Agriculture Organisation, International Atomic Energy Authority. Results of feeding trials of irradiated diets in human volunteers: summary of the Chinese studies. Rome: FAO, 1986. (Results reported at a seminar for Asia and the Pacific on the practical application of food irradiation, Shanghai, People's Republic of China, April 1986.)

\title{
The wasted opportunity of the election
}

Sir Bryan Thwaites, a professor of mathematics and chairman of Wessex Regional Health Authority, believes that the British public is sophisticated enough to recognise that the National Health Service cannot do everything that is medically possible and that therefore bounds and limits need to be set. ${ }^{1}$ The politicians fighting the election clearly do not agree. Most of the election debate has been about how much the various parties have spent or will spend, not about how to spend the money and what to spend it on. The time has clearly come to sit on the ground and talk not of the death of the NHS but of how to square exponentially increasing demand with necessarily limited resources. This was one of the themes of a recent conference at the Royal College of Physicians, reported by Dr Tony Delamothe (p 1440), and Sir Bryan in his foundation lecture last week to the University of Southampton Institute of Health Policy Studies tackled this most painful of subjects head on.

He was not the first by any means to recognise the expanding gap between what might be done and what is done. A BMA report of 1970 said: "The NHS has never since the early years been able to fully cope with the rising demands that it, and the parallel development of new methods of treatment, were responsible for stimulating." It has been fashionable for some time to laugh at the naivety of the belief of the NHS's architects that the new service could quickly mop up bad health and then cheaply maintain good health. Yet the current refusal of politicians to articulate in public what they know in private about the profound limitations of what can be afforded by either a taxation or an insurance based health service is to give the public debate an aura of fantasy not so different from that surrounding the birth of the NHS.

Sir Bryan used his mathematical background and the data supplied to him by his officers in Wessex to calculate that "expectations" are rising by $5 \%$ a year: "If capital and revenue were rolled up together it seems that we [in Wessex] could absorb 5\% more each year over the next five years without running any risk of criticism for waste or extravagance." He identified many factors that are fuelling this exponential increase in demand: public awareness of what can be provided; no charge at the point of delivery; lowered tolerance of discomfort; advances in medical knowledge leading to more complex treatments for more conditions; technological advances leading to diagnoses that would not otherwise have been made (he noted, in passing, that rates of change in microelectronics carry with them demands for capital replacement at unprecedentedly short intervals); demographic trends; more general practitioners, leading to more treatment, combined with more consultants, leading to more research (resulting in what the City calls a "high gearing effect"); and doctors' attitudes and expectations.

Resources cannot, of course, keep up with this demand. Sir Bryan looked back at the rate of growth in the NHS and showed how it was inevitably slowing: between 1957 and 1987 the NHS grew at about 4.5\% a year; between 1977 and 1987 growth slowed to 3.3\%; between 1982 and 1987 it 
was down to $1.4 \%$; and his projection for growth between 1983 and 1993 was $0.5 \%$. He then cut through the arguments over exactly how much the NHS has grown by in the very recent past and produced the figure below, which explains the constant double message the public gets: that the NHS is doing wonderfully and at the same time disintegrating. Both statements are true: it's all a matter of vantage point. He rammed home his message by saying that if growth continues at $2.5 \%$ while expectations increase at $5 \%$ then after a decade expectations will exceed resources by $27 \%$ and after another decade by $62 \%$.

So how can resources and demand be reconciled? The Economist addressed this issue a fortnight ago, agreeing with Sir Bryan that "the issue is not whether more billions should be spent but how to spend every pound to best effect." ${ }^{\text {It }}$ continued: "Individuals do that, day after day. So do companies. They succeed, more or less, because they face choice as consumers and competition as producers. The minimum duty of a state should be to replicate such choice and competition in its own affairs...." The Economist imagined that choice, competition, cost effectiveness, and incentives would settle the matter. Sir Bryan disagreed: "Each step forward in efficiency is frustrated by two steps backwards in the face of the onrush of expectation." Nor was he impressed by the "vast... discussion about alternative models and methods of funding the NHS." "It is pointless," he said, "to hope that any effective nett increase in resources for the NHS which might result from any of these structural changes would catch up with expectation which is independent of the financial arrangements."

Sir Bryan was for a fundamental rethinking of the NHS. He identified that the NHS acts of 1973 and 1977 gave the Secretary of State powers that he has hardly ever used, powers to decide what is a reasonable (and hence unreasonable) claim on the NHS and what lies within (and so without) the NHS. Sir Bryan thought that the Secretary of State would have to use these powers, and with his mathematical bent he

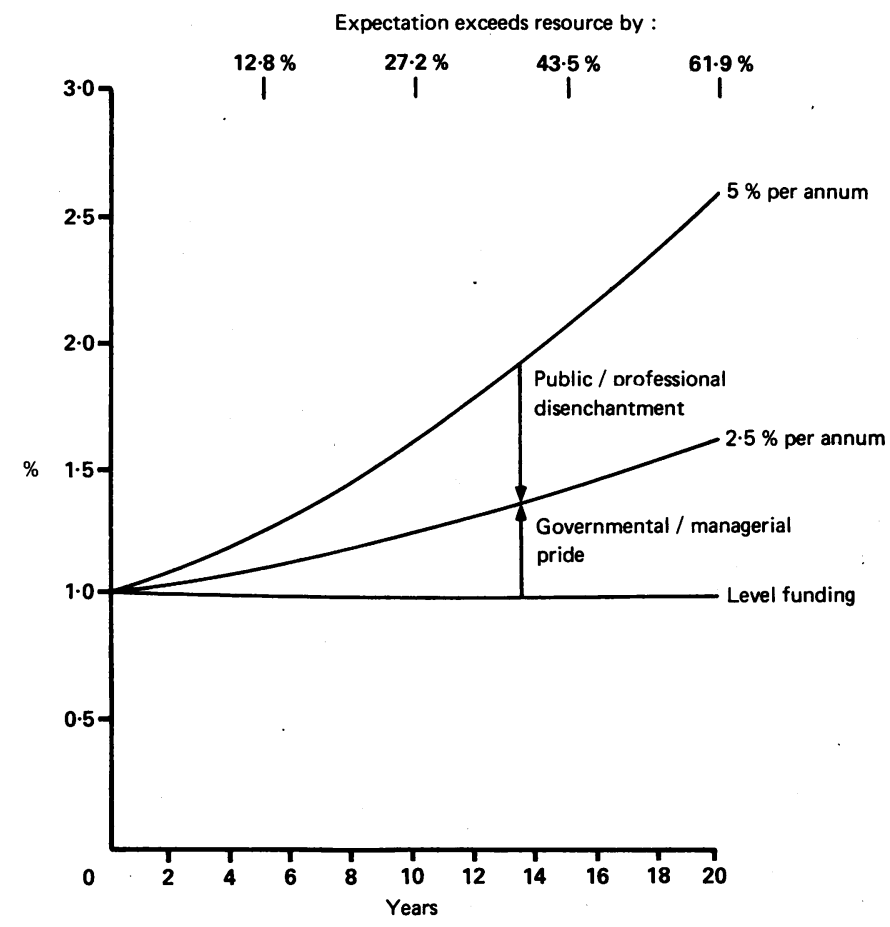

Increasing percentage difference between expectation and resource when they grow at different exponential rates. proposed (and illustrated) a three dimensional model for deciding what would be within (and so without) the NHS.

The first dimension would be medical conditions; a condition such as infertility might be decided to be without the service (as with in vitro fertilisation, where it is already almost the case). The second dimension he called "nonmedical assessment"; it included such considerations as ability to cope with after effects, responsibilities for others, and estimation of success of treatment (which seems to me to demand some medical assessment). This dimension has something to do with quality adjusted life years (QALYs), and Sir Bryan left his audience to contemplate whether they were exactly the same. His third dimension was cost of care and included far more measures than just the cost of specific treatment and hotel cost. Bravely, Sir Bryan put five cases into his restricted three dimensional NHS: the average man with arthritis and young wife expecting her first baby were safely inside; the married woman wanting in vitro fertilisation was just outside; and the fiancé with an unwanted tattoo and the unlikely survivor of heroic surgery were well outside.

These are the sort of painful decisions that will eventually have to be made (and are already made in corners on unarticulated and undebated grounds). But on what criteria will they be made and who will make them? Who will choose between vaccinating a homosexual against hepatitis $\mathrm{B}$, admitting the $950 \mathrm{~g}$ baby to the special care baby unit, transferring the moribund young man with a head injury to the regional neurosurgical unit, giving two sessions of psychotherapy to a neurotic housewife, and doing a second hip replacement on a 76 year old great grandmother? And how will they decide? Sir Bryan sat down just when the going was getting unbearably tough, but already he had gone further than most down a road that we will inevitably have to travel. He had made another attempt to start a public debate that doctors, the public, and politicians are all too unwilling to enter.

But could his questions have been even more fundamental? He began by quoting the 1946 act that established the health service: "It shall be the duty of the Minister of Health . . . to promote... the establishment of a comprehensive health service designed to secure improvement in the health of the people...." Could it be that the minister of health might have better ways than the health service to improve the health of the people? Certainly the enormous improvements of the past century in Britain have had little to do with the health services, and those in Third World countries struggling to improve the health of the people know that clean water and food, a sewerage system, improved education and housing, and social justice are much more important than doctors, drugs, and scalpels. Many of those who have worked in the Third World and lectured to the locals on these priorities have come back to Britain and suddenly realised that they should be listening to their own lectures. Maybe what is needed is a minister of health who has responsibility for much more than the health service and an ability to spend his money elsewhere.

Sir Bryan is thus to be congratulated for stepping where almost no man (and certainly no politician or chairman of a health authority) has gone before. But he and we have much further to go.

RICHARD SMITH

Assistant editor, $B M \mathcal{F}$

1 Thwaites B. The NHS: the end of the rainbow. Southampton: University of Southampton Institute of Health Policy Studies, 1987.

British Medical Association. Health services financing. London: BMA, 1970.

3 Anonymous. Underclass issues. Economist 1987 May 23:13-4. 